\title{
Quality of yellow passion fruit juice with cultivation using different organic sources and saline water
}

\author{
Calidad del jugo maracuyá amarillo cultivado con diferentes \\ fuentes orgánicas y agua salina
}

\author{
José Lucínio de Oliveira Freire ${ }^{1}$, Lourival Ferreira Cavalcante ${ }^{2}$, Alex Matheus Rebequi ${ }^{2 *}$, \\ Thiago Jardelino Dias ${ }^{2}$, Míriam Alice da Silva Brehm², Joao Batista dos Santos ${ }^{3}$
}

\begin{abstract}
The experiment was conducted in field in the municipaly Remigio, state of the Paraiba, Brazil, to evaluate the effects of the use of saline water for irrigation, bovine biofertilizer and mulch on the chemical characteristics of the fruits of yellow passion fruit. The experimental design was completely randomized in a factorial $2 \times 2 \times 2$, three replications and three plants per experimental unit. Study material consisted of irrigation with water is not saline $\left(0.50 \mathrm{dS} \mathrm{m}^{-1}\right)$ and saline $\left(4.50 \mathrm{dS} \mathrm{m}^{-1}\right)$, with and without application of bovine biofertilizer, with and without mulch. The use of bovine biofertilizer reduced the negative action of the salts, increasing the $\mathrm{pH}$, soluble solids and vitamin $\mathrm{C}$ in fruits of yellow passion fruit. The veal and mulching biofertilizer did not affect the titratable acidity values in passion fruit with an increased salt content of water. The content of vitamin $\mathrm{C}$ in fruits did not change with the use of mulch and biofertilizer veal. The ratio soluble solids / acidity of the passion fruit was reduced with the use of organic inputs and soil cover by applying saline water for irrigation of plants. The increasing salinity of irrigation water increased the electrical conductivity of the juice, regardless of the application of fertilizer and use of mulch.
\end{abstract}

Key words: Passiflora edulis, soluble solids, vitamin C, chemical attributes.

\section{RESUMEN}

El experimento se realizó en campo experimental del municipio de Remigio, estado de la Paraíba, Brasil, con el objetivo de evaluar los efectos del uso de agua salina en el riego, biofertilizante bovino y mantillo en las características químicas de los frutos del maracuyá amarillo. El diseño experimental fue de tres bloques al azar, con un arreglo factorial de $2 \times 2 \times 2$, tres repeticiones y

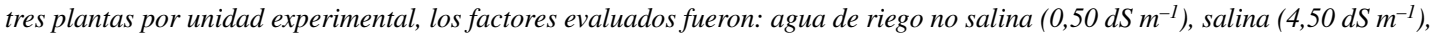
con o sin aplicación de biofertilizante bovino, con o sin mantillo. El uso de biofertilizante bovino redujo la acción negativa del sal, $p H$, sólidos solubles y los niveles de vitamina $C$ en el fruto de maracuyá amarillo. El biofertilizante bovino y el mantillo no influyeron en los valores de acidez titulable del maracuyá amarillo con el aumento del contenido de sal en el agua. El porcentaje de vitamina C en los frutos no cambió con el uso de mantillo y biofertilizante bovino. La razón de sólidos solubles y acidez titulable del maracuyá amarillo se redujo con el uso del insumo orgánico y mantillo al aplicar agua salina en el riego de las plantas. El aumento en la salinidad del agua de riego aumentó la conductividad eléctrica del jugo independientemente de la aplicación del biofertilizante y el uso del mantillo.

Palabras clave: Passiflora edulis; sólidos solubles; Vitamina C; atributos químicos.

\footnotetext{
Instituto Federal de Educação, Ciência e Tecnologia da Paraíba.

Universidade Federal da Paraíba.

3 Universidade Federal de Campina Grande.

* Corresponding author: lofeca@cca.ufpb.br
}

Fecha de Recepción: 17 Mayo, 2012.

Fecha de Aceptación: 2 Octubre, 2013. 


\section{Introduction}

Yellow passion fruit (Passiflora edulis Simms f. flavicarpa Deg.) is a plant highly sensitive to the action of salts; irrigation with saline water may have negative effects of the attributes of internal and external fruit quality (Costa et al., 2001; Cavalcante et al., 2003; Freire et al., 2010; Dias et al., 2011). This is a source of concern for farmers, rural businessmen and consumers with respect to the quality of the products.

The expansion of agricultural areas insufficient for the needs of the population, the high volume of water used in agriculture, the irregular distribution of precipitation and the decrease in the availability of good quality water in arid and semiarid zones makes it necessary to use saline water for agricultural production; this is happening in the passion fruit production regions in the semi-arid area of northeast Brazil. To obtain quality fruit which responds to the demands of consumers and the pulp processing industry of this region, yellow passion fruit producers must use appropriate technology to overcome the climatic and environmental limitations, adopting an adequate management of irrigation water (Porto Filho et al., 2009; Dias et al., 2011), as well as strategies which reduce the deleterious effects of salts on plants (Freire et al., 2011; Campos et al., 2011).

Lima Neto et al. (2010) indicated that the physiochemical evaluations most utilized to judge the quality of fruit products are soluble solids, titratable acidity, the ratio between these two which expresses the taste, $\mathrm{pH}$ and vitamin C. Cavalcante et al. (2003) indicated that the inconvenience of growing plants in saline soils and saline water requires research to determine viable technologies for the producers and thus minimize the deleterious effects of salt on the plants, since the use of saline water is almost obligatory for agriculture in these regions.

The use of techniques and bio-fertilizer produced by the anaerobic fermentation of bovine feces in order to reduce the noxious effects of saline soil and water are possibilities which have been tested in recent years to minimize the problems caused by salinization of soils, and thus provide a better use of saline irrigation water. Using saline water to irrigate soil with organic material such as bovine biofertilizer and mulch produced from plant remains has shown promising effects in mitigating the deleterious effects of salts in the majority of plants, and thus in the qualitative attributes of yellow passion fruit (Freire et al., 2010).

Using the hypothesis that the use of organic material in the soil may reduce the prejudicial action of salts on plants, the objective of this study was to evaluate the influence on the extrinsic qualities of the fruit of yellow passion fruit, of irrigation with saline water in a soil with bovine bio-fertilizer, with and without mulch,.

\section{Materials and Methods}

The study was performed between September, 2009 and April, 2010, using pressure lysimeters installed in the experimental field of Remigio $\left(6^{\circ} 53^{\prime} 00^{\prime \prime} \mathrm{S}, 36^{\circ} 02^{\prime} 00^{\prime \prime} \mathrm{W}\right)$, in the agricultural area of the Estado de Paraiba, Brazil. The climate is warm and humid; during the study period precipitation was $166 \mathrm{~mm}$ and the mean air temperature oscillated from $25^{\circ} \mathrm{C}$ to $28^{\circ} \mathrm{C}$.

Pressure lysimeters were constructed in plastic recipients with substrate capacity of $130 \mathrm{dm}^{3}(60 \mathrm{~cm}$ diameter $x 50 \mathrm{~cm}$ height) installed with a separation of $3.0 \times 3.0 \mathrm{~m}$ over a brick platform $30 \mathrm{~cm}$ above soil level. Two equidistant $1 \mathrm{~cm}$ diameter drainage holes were perforated in the internal base of each to collected drained solution. To avoid clogging of the holes a $2.5 \mathrm{~cm}$ layer of gravel was placed first, covered by a $5 \mathrm{~cm}$ layer of sand; the remainder was substrate. The substrate consisted of a mixture of soil removed from the top $10 \mathrm{~cm}$ of a eutrophic yellow ultisol (Santos et al., 2006), with bovine feces (C/N ratio $16 / 1$ and $12 \%$ humidity) in 10:1 volumetric proportion. The substrate was analyzed using the methodology proposed by Embrapa (2011), Table 1 .

The experimental design used randomized blocks with three repetitions in a $2 \times 2 \times 2$ factorial; the factors were electrical conductivity (EC) of irrigation water (non-saline $\mathrm{EC}=0.50 \mathrm{dS} \mathrm{m}^{-1}$, and saline $\mathrm{EC}=4.50 \mathrm{dS} \mathrm{m}^{-1}$ ); with and without bovine bio-fertilizer and with and without mulch, for a total of eight treatment combinations. Three plants were used per experimental unit. Plants were watered daily with $20 \%$ of the water layer evaporated during the previous day, measured in a class A tank installed beside the experimental zone.

The bovine bio-fertilizer was obtained by anaerobic fermentation of fresh cow feces mixed $1: 1$ with water without chlorine and left in a hermetically sealed container for at least 30 days (Santos \& Akiba, 1996). The methane gas produced 
Table 1. Physical and chemical characteristics of the substrate before planting seeds of yellow passion fruit.

\begin{tabular}{|c|c|c|c|}
\hline Physical & Values & Chemical & Values \\
\hline Sand $\left(\mathrm{g} \mathrm{kg}^{-1}\right)$ & 828 & pH (agua: 1:2.5) & 6.2 \\
\hline Silt $\left(\mathrm{g} \mathrm{kg}^{-1}\right)$ & 106 & $\mathrm{P}\left(\mathrm{mg} \mathrm{dm}{ }^{-3}\right)$ & 79.8 \\
\hline Clay $\left(\mathrm{g} \mathrm{kg}^{-1}\right)$ & 66 & $\mathrm{~K}^{+}\left(\mathrm{mg} \mathrm{dm}^{-3}\right)$ & 124 \\
\hline $\mathrm{ADA}\left(\mathrm{g} \mathrm{kg}^{-1}\right)$ & 26 & $\mathrm{Na}^{+}\left(\mathrm{cmol}_{\mathrm{c}} \mathrm{dm}^{-3}\right)$ & 0.29 \\
\hline $\mathrm{GF}(\%)$ & 60.6 & $\mathrm{Ca}^{2+}\left(\mathrm{cmol}_{\mathrm{c}} \mathrm{dm}^{-3}\right)$ & 3.95 \\
\hline ID $(\%)$ & 39.6 & $\mathrm{Mg}^{2+}\left(\mathrm{cmol}_{\mathrm{c}} \mathrm{dm}^{-3}\right)$ & 1.10 \\
\hline $\mathrm{D}_{\mathrm{s}}\left(\mathrm{Mg} \mathrm{m}^{-3}\right)$ & 1.26 & $\mathrm{H}^{+}+\mathrm{Al}^{3+}\left(\mathrm{cmol}_{\mathrm{c}} \mathrm{dm}^{-3}\right)$ & 165 \\
\hline $\mathrm{D}_{\mathrm{p}}\left(\mathrm{Mg} \mathrm{m}^{-3}\right)$ & 2.73 & $\mathrm{Al}^{3+}\left(\mathrm{cmol}_{\mathrm{c}} \mathrm{dm}^{-3}\right)$ & $<\mathrm{ADL}$ \\
\hline$P_{t}\left(m^{3} m^{-3}\right)$ & 0.54 & $\mathrm{CIC}_{\mathrm{pH} 7.0}\left(\mathrm{cmol}_{\mathrm{c}} \mathrm{dm}^{-3}\right)$ & 730 \\
\hline $\mathrm{A} / \mathrm{L}$ & 0.62 & $\mathrm{~V}(\%)$ & 77.4 \\
\hline $\mathrm{U}_{0.033 \mathrm{MPA}}\left(\mathrm{g} \mathrm{kg}^{-1}\right)$ & 103 & $\mathrm{MO}\left(\mathrm{g} \mathrm{kg}^{-1}\right)$ & 11.8 \\
\hline $\mathrm{U}_{0.1 \mathrm{MPA}}\left(\mathrm{g} \mathrm{kg}^{-1}\right)$ & 82.8 & $\mathrm{~B}\left(\mathrm{mg} \mathrm{dm}^{-3}\right)$ & 0.62 \\
\hline $\mathrm{U}_{1.0 \mathrm{MPA}}\left(\mathrm{g} \mathrm{kg}^{-1}\right)$ & 55.4 & $\mathrm{Fe}\left(\mathrm{mg} \mathrm{dm}^{-3}\right)$ & 36.0 \\
\hline $\mathrm{U}_{1.5 \mathrm{MPA}}^{1.0 \mathrm{MPA}}\left(\mathrm{g} \mathrm{kg}^{-1}\right)$ & 30.7 & $\mathrm{Cu}\left(\mathrm{mg} \mathrm{dm}^{-3}\right)$ & $<\mathrm{ADL}$ \\
\hline $\mathrm{A}_{\mathrm{di}}\left(\mathrm{g} \mathrm{kg}^{-1}\right)$ & 72.7 & $\operatorname{Mn}\left(\mathrm{mg} \mathrm{dm}^{-3}\right)$ & 6.80 \\
\hline TextureClass & Loamy & $\mathrm{Zn}\left(\mathrm{mg} \mathrm{dm}^{-3}\right)$ & 1.04 \\
\hline
\end{tabular}

ADA = clay dispersed in water; $G F=$ Degree of flocculence; $I D=$ Dispersion index $; D_{s}=$ Soil density $; D_{p}=$ Particle density, $\mathrm{P}_{\mathrm{t}}=$ Total porosity; $\mathrm{A} / \mathrm{L}=$ Clay/loam ratio; $\mathrm{U}_{\mathrm{cc}}=$ Soil humidity at field capacity; $\mathrm{U}_{\mathrm{pmp}}=$ Permanent wilting point; $\mathrm{A}_{\mathrm{di}}=$ Available water; CIC = Ionic Exchange capacity $-\left[\mathrm{SB}+\left(\mathrm{H}^{+}+\mathrm{Al}^{3+}\right)\right] ; \mathrm{V}=$ Saturation by bases $(\mathrm{SB} / \mathrm{CIC}) \times 100 ; \mathrm{MO}=$ Organic material; $\mathrm{ADL}=$ Under detection limit.

in the fermentation was liberated by means of a hose connected to the top of the biodigester; the other end of the hose was submerged in water to impede air entrance. Each lysimeter received $10 \mathrm{dm}^{3}$ of bovine bio-fertilizer diluted 1:1 with water and applied to the surface of the substrate, one week before and every 90 days after transplanting until the end of the experiment, as suggested by Cavalcante $e t$ al., (2007). The analytical measurements of the salinity of the diluted bovine bio-fertilizer and irrigation water using the methods of Richards (1954) and Embrapa (2011) are given in Table 2.

Bermuda grass (Cynodon dactylon L.) was used for mulch after drying at environmental temperature; a $10 \mathrm{~cm}$ layer was placed on the substrate surface. Mulch was replaced every two months.

Plantlets of yellow passion fruit were produced in polyethylene bags $(18 \mathrm{~cm}$ height, $13 \mathrm{~cm}$ diameter and transplanted to the pressure lysimeters in September, 2009. After careful study, plants $30 \mathrm{~cm}$ tall with 5 pairs of leaves were chosen. Before application of bovine bio-fertilizer and planting, the substrate in each lysimeter was fertilized with $150 \mathrm{~g}$ of simple superphosphate $\left(20 \% \mathrm{P}_{2} \mathrm{O}_{5}\right)$.

Substrates were watered 21 days after transplant (DAT) to saturation with their treatment solutions. At 30 DAT $10 \mathrm{~g}$ of fertilizer $(45 \% \mathrm{~N})$ was applied in the top soil level; after this $30 \mathrm{~g}$ fertilizer $(45 \%$ $\mathrm{N})$ and $50 \mathrm{~g}$ potassium chloride $\left(58 \% \mathrm{~K}_{2} \mathrm{O}\right)$ per plant was applied monthly. When flowering began, $50 \mathrm{~g}$ simple superphosphate per plant was applied.

At the peak of production, nine fruits with at least $30 \%$ of the skin yellow were collected per treatment. The fruits were shipped in polyethylene trays for chemical analysis in the Laboratory of Biology, Technology and Postharvest of the Universidad Federal de la Paraiba, Areia, Paraiba, Brazil.

The $\mathrm{pH}$ of the juice was determined by direct reading of a homogenized pulp sample in a Digimed DM-20 digital pH meter. Soluble solids (SS) content was determined with an Instrutherm ${ }^{\circledR}$ portable refractometer model RT-95 according to the Association of Official Analytical Chemists (2002). Titratable acidity (AT) was determined by adding three drops of phenolphthalein to $10 \mathrm{ml}$ juice, measured with $0.1 \mathrm{~N} \mathrm{NaOH}$; results were expressed in grams of citric acid per $100 \mathrm{~g}$ juice. The measurements of SS and AT were used to calculate the proportion SS/AT (Instituto Adolfo Lutz, 1985).

Vitamin $\mathrm{C}$ was quantified by tittering with a solution of DFI (2,6 dichloro-phenol-indophenol), using $1 \mathrm{ml}$ juice diluted in $50 \mathrm{ml}$ of $0.5 \%$ oxalic acid, according to Strohecker \& Henning (1967). Electrical conductivity (EC) of juice was determined by immersing the cells of a CDR-870 Instruthern ${ }^{\circledR}$ conductivity meter in a solution of juice, according to Porto Filho et al. (2009). 
Table 2. Salt characteristics of the bovine bio-fertilizer and irrigation water.

\begin{tabular}{lccc}
\hline Characteristic & Bio-fertilizer & Non-salty water & Salty water \\
\hline $\mathrm{pH}$ & 6.7 & 6.4 & 7.7 \\
$\mathrm{EC}\left(\mathrm{dS} \mathrm{m}^{-1}\right.$ at $\left.25{ }^{\circ} \mathrm{C}\right)$ & 2.55 & 0.50 & 4.50 \\
$\mathrm{RAS}\left(\mathrm{mmol} \mathrm{L}^{-1}\right)$ & 0.87 & 2.12 & 0.57 \\
$\mathrm{Ca}^{2+}\left(\mathrm{mmol}_{\mathrm{c}} \mathrm{L}^{-1}\right)$ & 13.7 & 1.67 & 2.80 \\
$\mathrm{Mg}^{2+}\left(\mathrm{mmol}_{\mathrm{c}} \mathrm{L}^{-1}\right)$ & 17.5 & 0.81 & 8.90 \\
$\mathrm{~K}^{+}\left(\mathrm{mmol}_{\mathrm{c}} \mathrm{L}^{-1}\right)$ & 3.33 & 0.11 & 0.43 \\
$\mathrm{Na}^{+}\left(\mathrm{mmol}_{\mathrm{c}} \mathrm{L}^{-1}\right)$ & 3.42 & 2.37 & 32.0 \\
$\mathrm{SO}_{4}^{2-}\left(\mathrm{mmol}_{\mathrm{c}} \mathrm{L}^{-1}\right)$ & 20.9 & 0.86 & 0.26 \\
$\mathrm{CO}_{3}{ }^{2-}\left(\mathrm{mmol}_{\mathrm{c}} \mathrm{L}^{-1}\right)$ & $<\mathrm{ADL}$ & 0.10 \\
$\mathrm{HCO}^{3-}\left(\mathrm{mmol}_{\mathrm{c}} \mathrm{L}^{-1}\right)$ & 2.50 & $\mathrm{ADL}$ & 3.20 \\
$\mathrm{Cl}^{-}\left(\mathrm{mmol}_{\mathrm{c}} \mathrm{L}^{-1}\right)$ & 10.0 & 112 & 40.8 \\
$\mathrm{Classification}^{-1}$ & $\mathrm{C}_{4} \mathrm{~S}_{1}$ & 3.14 & $\mathrm{C}_{4} \mathrm{~S}_{1}$ \\
\hline
\end{tabular}

$\mathrm{EC}$ - Electrical conductivity; RAS - Sodium absorption ratio $\left[\mathrm{Na}^{+} /\left(\mathrm{Ca}^{2+}+\mathrm{Mg}^{2+} / 2\right)^{1 / 2}\right]$; $\mathrm{ADL}$ - Under detection limit.

Results were interpreted by a factorial analysis of variance with Tukey a posteriori tests using an error rate of 5\%, according to Banzatto \& Kronka (2006).

\section{Results and Disscusion}

The $\mathrm{pH}$ of yellow passion fruit juice produced in substrates without bovine bio-fertilizer and irrigated with saline water was $5.4 \%$ lower than the $\mathrm{pH}$ without organic additives and irrigated with non-saline water (Figure 1); it decreased from 3.7 to 3.5. Similar behavior was observed with bovine bio-fertilizer; the $\mathrm{pH}$ of the juice decreased from 3.8 with non-saline water to 3.6 with saline water. These values agree with the results of Rodrigues et al. (2008), Freire et al. (2010) e Dias et al. (2011). The use of bovine bio-fertilizer, independent of the salinity of irrigation water, made the fruit juice less acid. The $\mathrm{pH}$ of the juice in all treatments was greater than 3.3, which according to Folegatti \& Matsuura (2002) is the ideal value to maintain juice quality during storage. $\mathrm{pH}$ values up to 4.2 do not limit the industrialization process, allowing a greater flexibility in the addition of sugar. More acid juice is more desirable for industrial processing, since it reduces the need to incorporate acidifiers and thus reduces processing costs and increases the useful life of the juice (Andrade \& Andrade, 2004).

Figure 2 demonstrates that, independent of the type of irrigation water and the use of mulch, bovine bio-fertilizer increased the titratable acidity of citric acid (AT) in the fruit. This behavior is consistent, since organic inputs have humic substances and thus organic acids and sugars which may be transported to the fruits (Nardi et al., 2002). Other authors also found similar results in yellow passion fruit cultivation using bovine bio-fertilizer (Freire et al., 2010; Dias et al., 2011). Andrade \& Andrade (2004) indicated that fruits with high AT levels are required by the processing industry, because they reduce the cost of artificial acidification in juice production.

In plants irrigated with non-saline water AT varied from 3.1 to $4.3 \%$, in treatments without bovine bio-fertilizer but with mulch, and with bio-fertilizer but without mulch, respectively. The results with non-saline water and bovine bio-fertilizer agree with those reported by Rodrigues et al. (2008), who obtained AT of 4.1-4.5\% in crops with bio-fertilizer and potassium.

In fruits irrigated with saline water, AT varied from $3.2 \%$ (without bovine bio-fertilizer but with mulch) and $4.1 \%$ (with bio-fertilizer but without mulch). For industrial uses, the acidity of yellow passion fruit juice should be between $3.2 \%$ and $4.5 \%$ (Folegatti \& Matsuura, 2002). Positive effect of the application of you substance organic in the chemical attributes of the fruits, it was also verified by Freire et al. (2010), that obtained an AT in the treatments without and with mulch, addition of bovine bio-fertilizer produced an increase of $24.7 \%$ and $17.2 \%$, respectively.

Except for the treatments without bovine biofertilizer or mulch (saline and non-saline water), in the rest of the treatments there was no significant interaction in the effects of bovine bio-fertilizer and mulch. This means that, although the EC maintained a high level in the fruit juice of plants with saline 


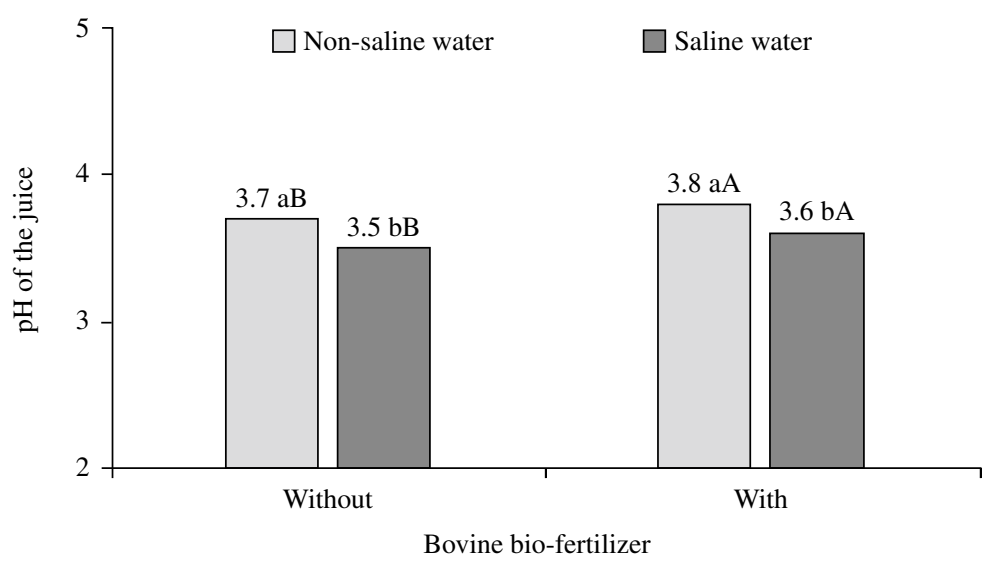

Figure 1. $\mathrm{pH}$ of yellow passion fruit juice grown with and without bovine bio-fertilizer in substrate irrigated with non-saline and saline water. Means followed by the same lower case letter between salinity conditions in the same fertilizer condition, and upper case letters in the same salinity conditions but different fertilizer condition, are not statistically different by the $\mathrm{F}$ test $(\mathrm{P} \leq 0,05)$.

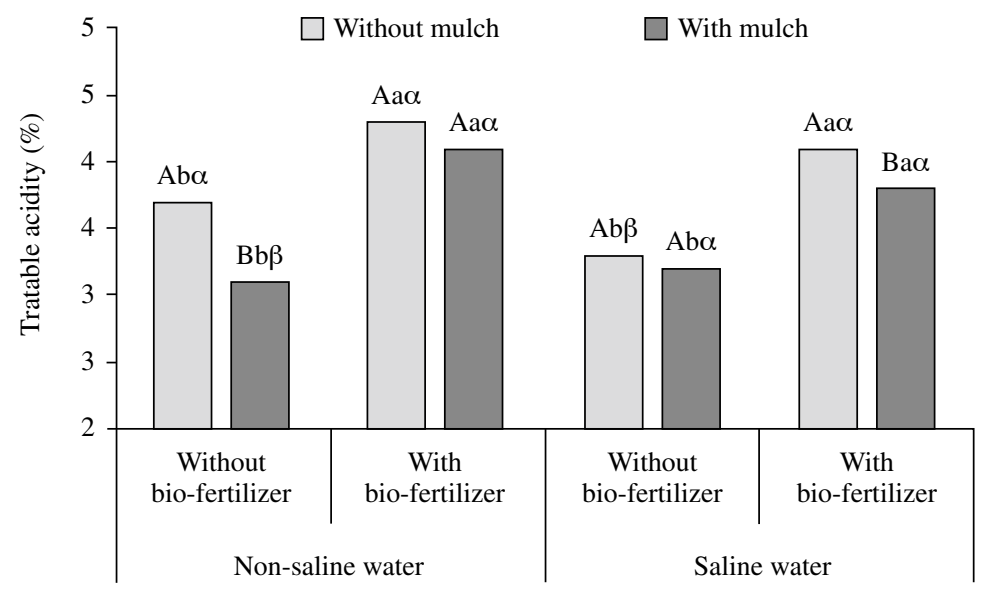

Figure 2. Citric titratable acidity (AT) in yellow passion fruit watered with non-saline and saline water, in substrate with and without bovine-bio-fertilizer, and with and without mulch. Capital letters compare mulch with the same conditions of water salinity and use of bio-fertilizer; lower case letters compare bovine bio-fertilizer in the same conditions of water salinity and mulch; Greek letters compare water salinity under the same conditions of bovine bio-fertilizer and mulch. Means followed by the same letter are not statistically different ( $\mathrm{F}$ test, $\mathrm{P} \leq 0.05)$.

water (Figure 6A, 6B), there was not enough effect of the salt to reduce AT significantly, taking into consideration the interaction of water type $v s$. biofertilizer $v s$. mulch.

Independent of the use of bio-fertilizer, the increase in the content water salinity produced a notable decrease in the content of soluble solids (SS) of the fruits (Figure 3). In spite of this reduction the fruits produced in the treatments with biofertilizante, irrigated non saline and saline water were $15,7 \%$ and of $17,3 \%$ larger respectively, that the treatments without the bovine biofertilizante. This fact evidences that the organic input favored the formation of you sugar in the fruits produced with saline water. In the fruit irrigated with less saline water and with bovine bio-fertilizer the SS values increased 7,10\%.

In the evaluation of the chemical quality of yellow passion fruit, Freire et al. (2010) reported that the highest mean SS values were found in plants irrigated with good quality water without bio-fertilizer $\left(12.59^{\circ} \mathrm{Brix}\right)$, with an increase $18.1 \%$ greater than with bio-fertilizer. Costa et al. (2001) reported from 14.0 to $15.9^{\circ}$ Brix for yellow passion fruit irrigated with saline water; Cavalcante et al. 


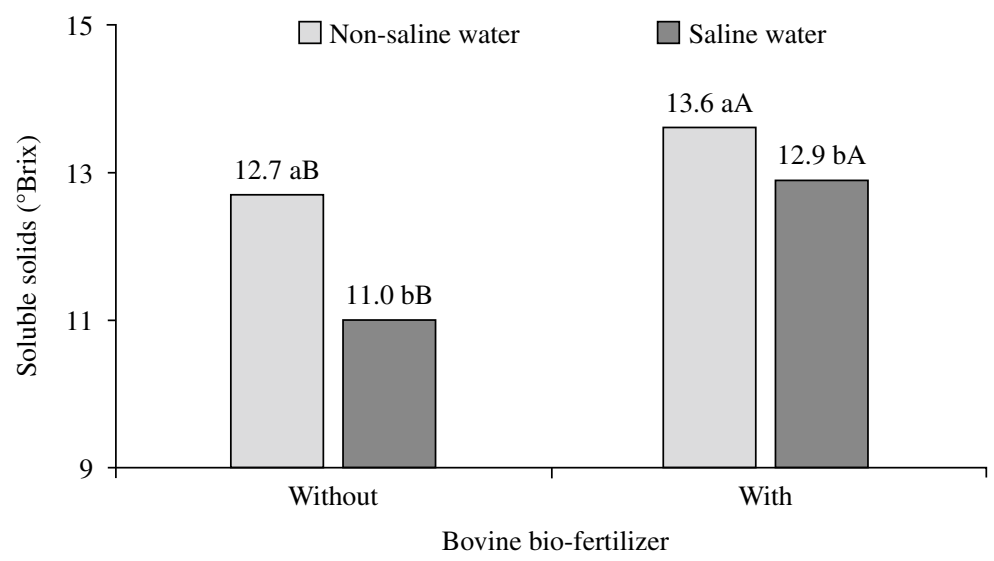

Figure 3. Levels of soluble solids (SS) in fruits of yellow passion fruit produced in substrate with and without bovine bio-fertilizer and irrigated with non-saline and saline water. Lower case letters refer to different salinity conditions in the same fertilizer treatment; upper case letters refer to different fertilizer treatments in the same salinity condition. Means followed by the same letter are not statistically different $(\mathrm{F}$ test, $\mathrm{P} \leq 0.05)$.

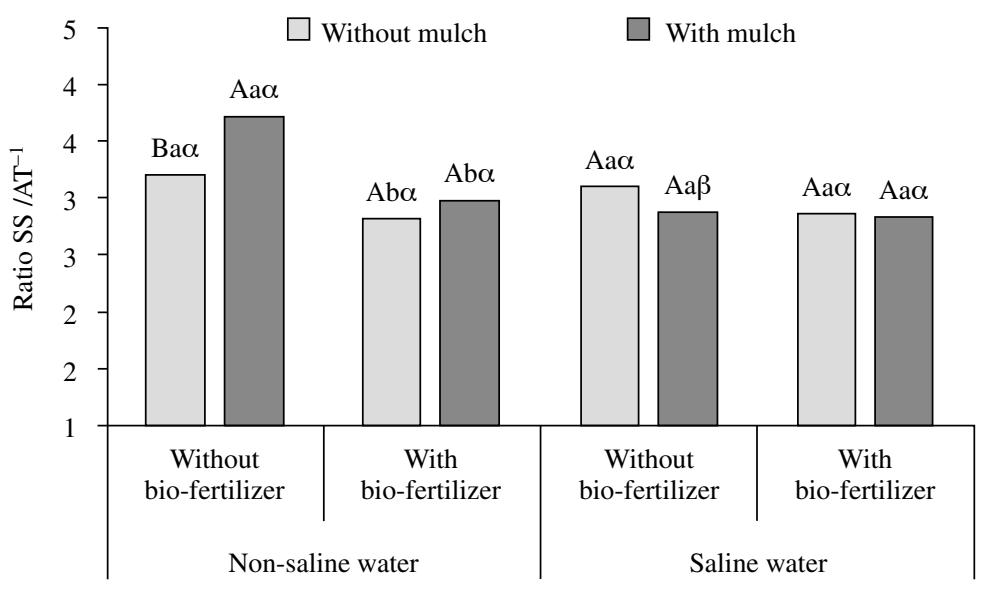

Figure 4. Ratio of soluble solids to citric titratable acidity (SS/AT) in fruits of yellow passion fruit with and without bovine biofertilizer, with and without mulch watered with non-saline and saline water. Capital letters compare mulch with the same conditions of water salinity and use of bio-fertilizer; lower case letters compare bovine bio-fertilizer in the same conditions of water salinity and mulch; Greek letters compare water salinity under the same conditions of bovine bio-fertilizer and mulch. Means followed by the same letter are not statistically different $(\mathrm{F}$ test, $\mathrm{P} \leq 0.05)$.

(2003) \& Hafle et al. (2009) reported SS levels from 13.5 to 14.0 and 12.8 to $13.5^{\circ}$ Brix, respectively. Except for the fruit obtained with saline water and without biofertilizer, the treatments are adequate for industrialization, because according to LimaSilva et al. (2002) fruit with more than $12^{\circ}$ Brix may be used in industrial processing, with lower production costs and positive effects on the quality of the processed product.
The SS/AT ratio of fruits produced witout bovine bio-fertilizer, with mulch and irrigated with less saline water $(\mathrm{SS} / \mathrm{AT}=3.72)$ was $29 \%$ greater than that of plants treated with the same additions but irrigated with saline water $(\mathrm{SS} / \mathrm{AT}=2.88)$ (Figure 4). For fruit produced with less saline water, using organic residues decreased the SS/ AT ratio by $13 \%$ and $25 \%$ with and without mulch, respectively. This suggests that the use of bovine 
bio-fertilizer produced in increase in AT (Figure 2) due to the levels of organic acids in the residues, with a consequent reduction in the relation between the levels of SS and AT (Porto Filho et al., 2009; Dias et al., 2011).

The SS/AT ratios reported here are inferior to the values of 4.2-5.2 accepted as ideal by Haendler (1965); however, they agree with the 3.0 proportion reported by Dias et al. (2011) for yellow passion flower fruit produced witn organic additive. As well as being one of the most rapid methods to evaluate the taste of fruits for their sweetness and acidity (Pinheiro et al., 2006), the SS/AT ratio is one of the best ways to evaluate the sweetness of the product (Folegatti \& Matsuura, 2002), which may be influenced by the maduration stage of the fruit and the crop management conditions, which may be reflected in possible abiotic stress during the process of fruit formation (Silva et al. 2008).

Independent of water salinity, the bio-fertilizer had a positive influence on the level of vitamin C in the fruit (Figure 5). With saline water irrigation values only increased by $7 \%$, from 22.2 to $23.8 \mathrm{mg}$ $100 \mathrm{~mL}^{-1}$, but with non-saline water the increase was $19 \%$. This effect of bovine bio-fertilizer is compatible with the highest levels of SS (Figure 3), since vitamin $C$ production is related to the sugars present in yellow passion fruit juice which the plant synthesizes ascorbic acid from hexose sugars such as D-glucose and D-galactose (Fortaleza et al., 2005).

According to Dias et al. (2011), application of bovine bio-fertilizer increases and water salinity decreases the vitamin $C$ content of juice, possibly due to a greater concentration of salts in the leaf tissue that modifies the biochemical and physiological processes of the plants, changing photosynthetic activity and the percentage of assimilates in the plant (Tester \& Davenport, 2003). In fruits produced in substrates without mulch, the use of bovine biofertilizer increased vitamin C content by $15 \%$, from 19.4 to $22.4 \mathrm{mg} 100 \mathrm{~mL}^{-1}$, while we treatment with mulch the content vitamin C not differ (Figure 5B). Freire et al. (2010) and Dias et al. (2011) suggested that the organic acids and sugars present in organic sources available to the plants may increase vitamin $\mathrm{C}$ levels in the fruit.

The EC of the juice increased with the ionic content of irrigation water (Figure 6). EC increased by $36 \%$ under saline irrigation without bio-fertilization (Figure 6A), analogous to the results with and without mulch in the substrate (Figure 6B). According to Porto Filho et al. (2009), the EC of fruit increases significantly with greater accumulation of salts in the soil due to irrigation with more salty water, which according to Mendlinger (1994) and Moura et al. (1999) risks the postharvest quality of the fruits due to the nature and concentration of ions, solubility, ionic mobility and viscosity as a result of the level of salt stress and the tolerance level of the plant.

The treatments without bovine bio-fertilizer no produced significant effect on EC in the fruits of plants irrigated with non-saline water, the mean EC was $4.7 \mathrm{dS} \mathrm{m}^{-1}$. In the treatments with bio-fertilizer irrigated saline $\left(4.5 \mathrm{dS} \mathrm{m}^{-1}\right)$ e non-saline water,
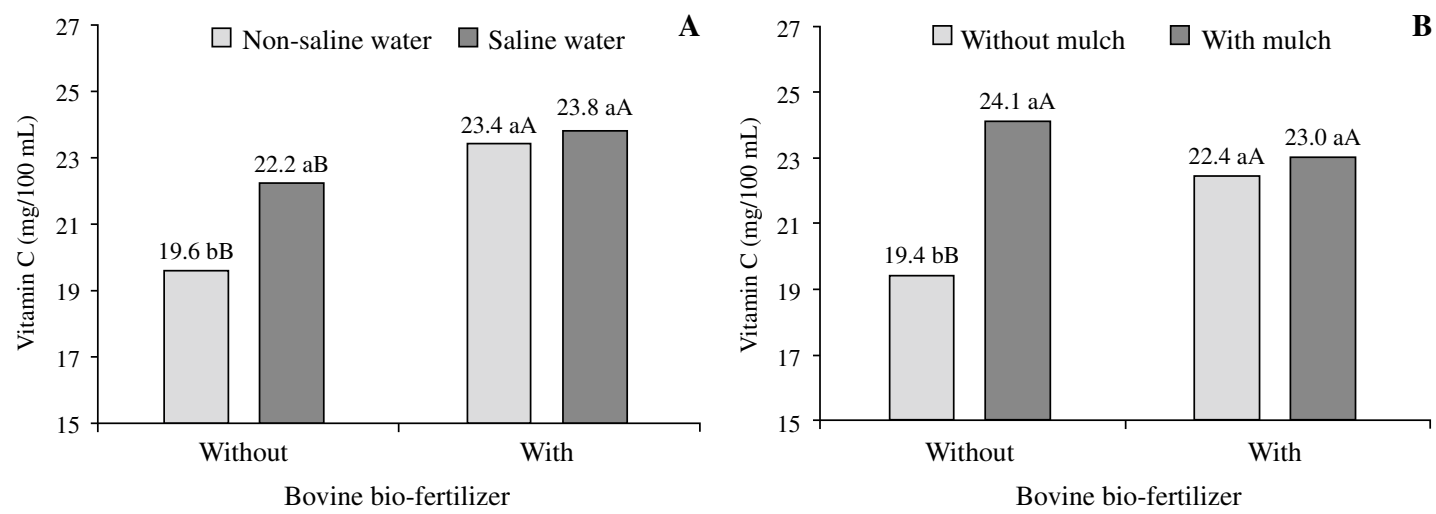

Figure 5. Vitamin C concentration in fruits of yellow passion fruit cultivated in substrate with and without bovine bio-fertilizer (A) and with and without mulch (B) as a function of water quality (non-saline and saline). In Figure 5A lower case letters compare salinity conditions under the same fertilizer condition and upper case letters compare the fertilizer condition in with the same water quality. In Figure 5B lower case letters compare fertilizer condition under the same mulch conditions, while upper case letters compare mulch use under the same fertilizer condition. Means followed by the same letter are not statistically different $(\mathrm{F}$ test, $\mathrm{P} \leq 0.05)$. 

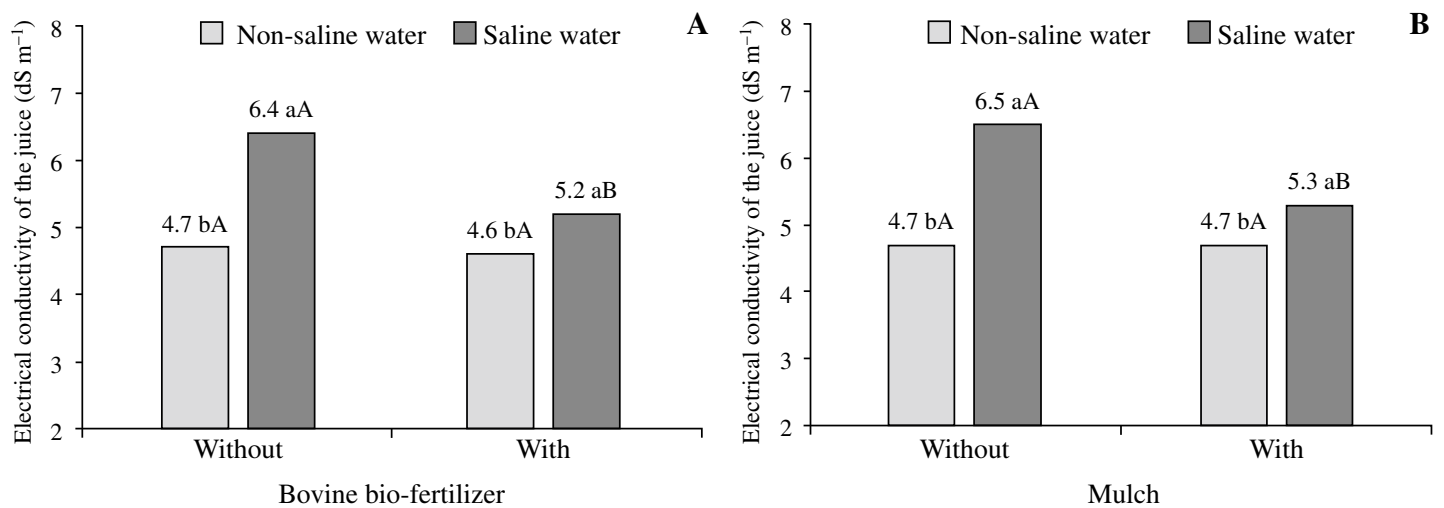

Figure 6. Electrical conductivity (EC) of the juice of fruits of yellow passion fruit irrigated with non-saline and saline water, with and without bovine bio-fertilizer (A) and with and without mulch (B). In Figure 6A, lower case letters compare salinity conditions with the same fertilizer condition, while upper case letters compare fertilizer conditions under the same salinity condition. In Figure 6B, lower case letters compare salinity conditions under the same conditions of mulch use, while upper case letters compare conditions of mulch use under the same salinity condition. Means followed by the same letter are not statistically different $(\mathrm{F}$ test, $\mathrm{P} \leq 0.05)$.

the EC reduced from 5.2 to $4.6 \mathrm{dS} \mathrm{m}^{-1}(11 \%)$, respectively, indicating the attenuation of the effects of saline water on the chemical quality of the fruit (Figure 6A). Thus both bovine bio-fertilizer and mulch mitigated the effects of water salinity on the fruit of plants (Figure 6B); mulch reduced the ionic content in fruit juice by $1.2 \mathrm{dS} \mathrm{m} \mathrm{m}^{-1}$. Nardi et al. (2002) and Baalousha et al. (2006) suggested that this effect is associated with the production of organic solutes such as sugars, free amino acids and proline liberated by the organic additions to the substrate, which increases the capacity of the plants to adapt to the depressive effects of salts, especially in the case of bovine bio-fertilizer which probably has a greater quantity of these products since it was applied in liquid form after a fermentation process.

\section{Conclusions}

The use of bovine bio-fertilizer mitigated the depressive effects of salts, increasing the $\mathrm{pH}$, soluble solids and vitamin $\mathrm{C}$ levels in the fruits of yellow passion fruit.

Bovine bio-fertilizer and mulch did not affect the values of titratable acidity in yellow passion fruit with the increase in salt in irrigation water.

The ratio of soluble solids to titratable acidity in yellow passion fruit decreased with the use of organic additive and mulch under irrigation with saline water.

The salinity of the juice was greater in fruit produced with saline water irrigation, independent of the application of bovine bio-fertilizer and mulch.

\section{Literature Cited}

Andrade, J.M.B.; Andrade, A.B.

2004. Características físico-químicas do maracujá amarelo produzido em diferentes épocas em Marumbi-PR. Arquivo Apadec, Meio Ambiente, pp. 391-397.

Association Of Official Agricultural Chemists 2002. Official methods of analysis of the association of official analytical chemistry. ed.17. Washington, pp. 1115.

Baalousha, M.; Motelica-Heino, M.; Coustumer, P. 2006. Conformation and size of humic substances: effects of major cátion concentration and type, $\mathrm{pH}$, salinity, and resistence time. Coloids and Surface A: Physicochemical Engineering Asppects, 272 (1): 48-55.
Banzatto, D.A.; Kronka, S.N.

2006. Experimentação Agrícola. Jaboticabal: FUNEP, 247 p. Campos, V.B.; Cavalcante, L.F.; Prazeres-Campos, S. da S.; Gheyi, H.R.; Chaves, L.H.G.; Mesquita, F. de O.

2011. Esterco bovino líquido em luvissolo sódico: I. Resposta biométrica e produtiva do maracujazeiro amarelo. Idesia, 29 (2): 59-67.

Cavalcante, L.F.; Andrade, R.; Mendonça, R.M.N.; Silva, S. M.; Oliveira, M.R.T.; Araújo, F.A.R.; Cavalcante, I.H.L.

2003. Caracterização qualitativa de frutos do maracujá amarelo (Passiflora edulis f.flavicarpa Deg.) em função da salinidade da água de irrigação. Agropecuária Técnica, Areia, 24 (1): 34-45. 
Cavalcante, L.F.; Santos, G.D.; Oliveira, F.A.; Cavalcante, I.H.L.; Gondim, S.C.; Cavalcante, M.Z.B.

2007. Crescimento e produção do maracujazeiro amarelo em solo de baixa fertilidade tratado com biofertilizantes líquidos. Revista Brasileira de Ciências Agrárias, Recife, 2 (1): 15-19.

Costa, J.R.M.; Lima, C.A.A.; Lima, E.D.A.; Cavalcante, L.F.; Oliveira, F.K.D.

2001. Caracterização dos frutos de maracujá amarelo irrigados com água salina. Revista Brasileira de Engenharia Agrícola $e$ Ambiental, Campina Grande, 5 (1): 143-146.

Dias, T.J.; Cavalcante, L.F.; Freire, J.L. de O.; Nascimento, J.A.M. do.; Beckmann-Cavalcante, M.Z.; Santos, G.P. dos 2011. Qualidade química de frutos do maracujazeiro-amarelo em solo com biofertilizante irrigado com águas salinas. Revista Brasileira de Engenharia Agrícola e Ambiental, Campina Grande, 15 (3): 229-236.

EMBRAPA-Empresa Brasileira de Pesquisa Agropecuária 2011. Manual de Métodos de Análise de Solos. 3 ed. Atualizada. Rio de Janeiro, 230 pp.

Folegatti, M.I.S.; Matsuura, F.C.A.U.

2002. Produtos. In: Matsuura, F.C.A.U.; Folegatti, M.I.S. (ed.). Maracujá pós-colheita. Brasília: EMBRAPA, pp. 42-47.

Fortaleza, J.M.; Peixoto, J.R.; Junqueira, N.T.V.; Oliveira, A.T.; Rangel, L.E.P.

2005. Características físicas e químicas em nove genótipos de maracujá azedo cultivado sob três níveis de adubação potássica. Revista Brasileira de Fruticultura, Jaboticabal, 27 (1): 124-127.

Freire, J.L.O.; Cavalcante, L.F.; Rebequi, A.M.; Dias, T.J.; Souto, A.G.L.

2011. Necessidade hídrica do maracujazeiro amarelo cultivado sob estresse salino, biofertilização e cobertura do solo. Revista Caatinga, Mossoró, 24 (1): 82-91.

Freire, J.L.O.; Cavalcante, L.F.; Rebequi, A.M.; Nunes, J.C.; Dias, T.J.; Cavalcante, I.H.L.

2010. Atributos qualitativos do maracujá amarelo produzido com água salina, biofertilizante e cobertura morta no solo. Revista Brasileira de Ciências Agrárias, Recife, 5 (1): 102-110.

Haendler, L.

1965. La passiflora: Sa composition chimique et sés possibilités de transformation. Fruits, 20: 235-245.

Hafle, O.M.; Ramos, J.D.; Lima, L.C.O.; Ferreira, E.A.; Melo, P.C. 2009. Produtividade e qualidade de frutos do maracujazeiro amarelo submetido à poda de ramos produtivos. Revista Brasileira de Fruticultura, 31 (3): 763-770.

Instituto Adolfo Lutz

1985 Normas analíticas, métodos químicos e físicos para análises de alimentos. $3^{\mathrm{a}}$ ed. São Paulo: Instituto Adolfo Lutz, 533 pp.

Lima Neto, I.S.; Guimarães, I.P.; Batista, P.F.; Aroucha, E.M.M.; Queirós, M.A.

2010 Qualidade de frutos de diferentes variedades de melancia provenientes de Mossoró-RN. Revista Caatinga, 23 (4): 14-20.
Lima-Silva, P.S.; Sá, W.R.; Mariguele, K.H.; Barbosa, A.P.R.; Oliveira, D.F.

2002 Distribuição do teor de sólidos solúveis totais em frutos de algumas espécies de clima temperado. Revista Caatinga, 15 (1-2): 19-23.

Medeiros, S.A.F.; Yamanishi, O.K.; Peixoto, J.R.; Pires, M.C.N.; Junqueira, T.V.; Ribeiro, J.G.B.L.

2009 Caracterização físico-química de progênies de maracujá roxo e maracujá amarelo cultivados no Distrito Federal. Revista Brasileira de Fruticultura, 31 (2): 492-499.

Mendlinger, $S$.

1994 Effect of increasing plant density and salinity on yield and fruit quality in muskmelon. Scientia Horticulturae, 57: 41-49,

Moura, S.C.S.R.; Vitali, A.A.; Hubinger, M.D.

1999 A study of water activity and electrical conductivity in fruit juices: Influence of temperature and concentration. Brazilian Journal Food Technology, 2: 31-38.

Nardi, S.; Pizzeghello, D.; Muscolo, A.; Vianelo, F. 2002. Physiological effects of humic substances on higher plants. Soil Biology \& Biochemistry, 34 (4): 1527-1536.

Pinheiro, A.M.; Fernandes, A.G.; Fai, A.E.C.; Prado, G.M. do; Sousa, P.H.M. de; Maia, G.A.

2006. Avaliação química, físico-química e microbiológica de sucos de frutas integrais: Abacaxi, caju e maracujá. Ciência e Tecnologia de Alimentos, 26: 98-103.

Porto Filho, F.Q.; Medeiros, J.F.; Senhor, R.F.; Morais, P.L.D.; Menezes, J.B.

2009. Qualidade de frutos do melão amarelo irrigado com água de diferentes níveis de salinidade. Caatinga, 22 (1): 193-198.

Richards, L.A.

1954. Diagnostico y rehabilitacion de suelos salinos y sodicos. Departamento de Agricultura de los Estados Unidos de la America, 172 pp.

Rodrigues, A.C.; Cavalcante, L.F.; Dantas, T.A.G.; Campos, V.B.; Diniz, A.A.

2008. Caracterização de frutos de maracujazeiro amarelo em solo tratado com "biofertilizante supermagro" e potássio. Magistra, 20 (3): 264-272.

Santos, A.C.V.; Akiba, F.

1996 Biofertilizante líquido: uso correto na agricultura alternativa. Seropédica: UFRRJ. 35 pp.

Santos, H.G.; Jacomine, P.K.T.; Anjos, L.H.C.; Oliveira, V.A.; Oliveira, J.B.; Coelho, M.R.; Lumbrebas, J.F.; Cunha, T.J.F. 2006. Sistema brasileiro de classificação de solos. 2ed. Rio de Janeiro: Embrapa Solos. 306 pp.

Silva, T.V.; Resende, E.D.; Viana, A.P.; Pereira, S.M.F.; Carlos,

L.A.; Vitorazi, L.

2008. Qualidade do suco de maracujá-amarelo em diferentes épocas de colheita. Ciências e Tecnologia de Alimentos, 28: 545-550.

Strohecker, R.; Henning, H.M.

1967. Analisis de vitaminas: métodos comprovados. Madrid: Paz Montalvo, 428 pp.

Tester, M.; Davenport, R.

2003. $\mathrm{Na}^{+}$tolerance and $\mathrm{Na}^{+}$transport in higher plants. Annals of Botany, 91: 503-527. 
